Carlos Petit (2017). Arte y derecho mercantil. Madrid:

Marcial Pons, Ediciones Jurídicas y Sociales.

\title{
Crédito público, derecho mercantil y arte del grabado
}

Antes que nada, iqué es una recensión (o reseña como algunos prefieren llamarla a este lado del Atlántico)? Tal como sucede en otros géneros académicos, no hay una regla de oro, ni siquiera una teoría definida al respecto; esto es, tanto sobre su concepto como sobre su función. Dejo allí una idea para colegas, antes de que esto lo ocupe un manual bibliométrico y termine definiendo la reseña a partir del número de palabras y de citas realizadas. Pero no nos desviemos. Dentro del mercado, metafóricamente hablando, de reseñas, hay de todo. Y dentro de ese variopinto está la regla que me he impuesto hasta el momento: que la reseña sea una invitación al lector, trazándole lo que puede encontrar y aportándole algunas luces que le permitan sacar un mejor provecho a la obra reseñada; todo esto sin reemplazarle, jamás, su propia experiencia de lectura, de la que él sería el único responsable. Lo anterior supone, entonces, que la reseña es un ejercicio escritural intermedio entre dos lecturas, la de quien reseña y la de quien lee la reseña. Pero, incluso, dicha escritura intermedia corresponde con un deseo de objetivar la lectura previa, la de quien reseña. En este sentido, podría decirse que una reseña, más que una escritura, es un conjunto de lecturas, objetivadas o no, puestas unas sobre otras.

Además, este ejercicio solo logra ser exitoso si el lector de la reseña se interesa por leer lo reseñado, suponiendo, claro está, que se reseña una buena obra. Si este es el objetivo de una reseña, como lo creo yo, y si seguimos el método teleológico, tendríamos varias conclusiones de entrada: i) una reseña debe motivar al lector para que siga su trayectoria lectora; es decir, que una vez deje de leer la reseña, lea lo reseñado. ii) La reseña debe motivar, como retórica que es, pero dado que estamos en el campo académico, esta motivación supone, sin ser lo único, un ejercicio intelectual que debe quedar plasmado en la propia reseña. iii) Pero este componente intelectual debe ser limitado, pues de lo contrario se pierde el fin mismo del género: si se convierte en un resumen demasiado completo termina por reemplazar al texto reseñado y el lector, por aquella ley de la conservación de la energía, no irá adonde debería haber ido; igual, si una reseña es muy crítica, 
desvirtúa el género en la medida en que el lector, quien generalmente no ha leído lo reseñado, decidirá por eso no leer la obra y quedará solamente con la perspectiva del reseñador. Si una obra no vale la pena, ipara qué reseñarla? ¿Qué tan válido es un texto, en este género, que invita a no-leer otra cosa? En este sentido, la crítica demoledora sería más apropiada para el formato de artículo científico, por dar un ejemplo, que para el de la reseña.

Entonces, una reseña, desde lo que acabo de decir y a mi modo de ver, sería una invitación, con una carga académica importante pero no exclusiva, al lector para que este sepa qué puede encontrar en lo reseñado y, desde allí, decida si asume o no la lectura sugerida. Igualmente, la reseña podría brindar, cual caja de herramientas, algunos conceptos que le ayudarían al lector una mejor comprensión hermenéutica. Pero hasta ahí.

Y siguiendo esto, procedo a hacer una reseña de un texto que conocí en su proceso de construcción y al que quiero invitar a su lectura a mi lector, si es que llego a tener alguno. Y lo hago porque fui un testigo privilegiado, por la gracia de su autor, del desarrollo de la obra. Su origen está en una nota de pie de página de un texto anterior: Historia del derecho mercantil (Petit, 2016). Allí Petit, mientras exponía la Real Compañía de Comercio de Barcelona, se dio cuenta del valor estético de sus acciones, por lo que en una nota de pie de página escribió:

Dejo aparte consideraciones artísticas sobre las láminas de las accionestítulos: cfr. Alexander Kipfer, Historische Wertpapiere, pp. [141] ss. con especímenes (grabados y manuscritos) de las compañías hispanas. Para Kipfer estos bellos documentos, sin equivalentes de calidad comparable en otros confines de Europa, serían «uwelen frühkapitalistischer MerkantilDokumentation aus dem 18. Jahrhundert» (p. 11) (Petit, 2016, p. 183, n. 70).

Es decir, «joyas de la documentación mercantil protocapitalista del siglo XVIII». Lo llamativo es que Petit no se quedó con solo enunciar el valor artístico de tales documentos, sino que, a partir de dicha nota, asumió una investigación que ahora muestra sus frutos al público académico o, más bien, a los interesados en la historia de la economía, del arte y del derecho.

Y aquí viene mi primer punto de referencia a la obra reseñada: la interdisciplinariedad. El texto, expresamente, hila estos tres componentes en el siglo XVIII español: la aparición del crédito público, el desarrollo del grabado que acompañó los documentos que hacían constar el crédito público 
y la transformación del derecho mercantil desde una faceta corporativa a una protocapitalista-liberal. Esta particularidad interdisciplinaria supone el culmen de los nuevos trabajos de iushistoria que han sabido, con mucho bien para la profesión, ir más allá de la historia meramente institucional de nuestros abuelos, y es lo que se advierte prima facie en la obra que reseño. Pero entiéndaseme bien, no hago apología del rechazo a la historia institucional hecha por nuestros antepasados en la iushistoria, que parece ser el credo de algunos colegas, sino un elogio de aquellos textos, como el de Petit, que parte de lo que nos legaron para abordar, hoy día, temas más culturales y, por tanto, interdisciplinares. ${ }^{1}$ Esto, claro está, porque el derecho no es, nunca lo fue, un fenómeno por fuera de la cultura, la cual no podemos dejar de lado si buscamos la comprensión de lo que se entendió por derecho, que, como su etimología indica (del latín comprehendere), busca articular, unir y no separar o aislar.

Agrego, para cerrar este punto, que, como pocas veces puede verse, el autor se mueve con destreza en estos tres mundos que hila con asombroso detalle. Hay que conocerlo personalmente para saber, de entrada, que es un iushistoriador, pues de lo contrario bien podría creerse que es originalmente un historiador del arte o de la economía.

Creo que ahora es el momento prudente de hacer un pequeño recuento de lo que la obra pretende; recuento que debe dar solo pautas básicas de comprensión para una futura lectura, por lo que no ahondaremos en los detalles ni en los argumentos demostrativos. Este trabajo de Petit busca explicar la transformación del derecho comercial, desde el ius mercatorum, con sus usos propios del Antiguo Régimen anclado en un marco católico y corporativo, hasta el derecho mercantil, mayormente liberal y, por tanto, basado en el crédito público y la mayor circulación posible de los títulos-valores. Esto es, mostrar cómo el crédito dejó de ser propiedad exclusiva del comerciante (asunto que solo puede comprenderse desde los valores de la actividad mercantil del Antiguo Régimen; valores que determinaron la praxis de la profesión [Petit, 2016, pp. 25-86]), para ser, paulatinamente, algo del dominio público (Petit, 2017, p. 145). Esta transformación se vivió inicialmente, en el caso español, en el siglo XVIII, el siglo ilustrado, y justo por la pérdida creciente del valor cohesionador de la

1 Verbigracia, Petit (2017, p. 15), en la nota 4, nos deja en claro que parte, sin quedarse allí, de lo que su maestro, todo un institucionalista, le legó. Me refiero a la magnífica obra Historia del derecho mercantil. Estudios de José Martínez Gijón (1999). 
fe, ${ }^{2}$ lo que facilitó la irrupción de una nueva creencia: la que está en el fondo del crédito público (la confianza en que el poder responderá por la deuda que se circunscribe en el documento); transformación que buscaba, además, una revolución de los medios de pago y de la recaudación de dinero (esto es, acciones, vales, cédulas, incluso billetes de lotería, etc. [Petit, s.f.]). Lo interesante es que el poder público (en términos de la época, la policía [Mannori y Sordi, 2013, II-3 y 4, pp. 127-181]) se fue transformando igualmente para abarcar, en un sentido paterno, cada vez más asuntos que antes eran exclusivos del lento devenir de la costumbre, como la censura (Conde, 2006), la legislación (Grossi, 2003) y la economía, por enunciar tres situaciones. Esta policía o poder público, en un adagio de pragmatismo en el tema que nos ocupa, recurrió (i) como forma de romper los esquemas antiguos para que no llenasen de escepticismo los nuevos papeles del crédito público, y (ii) como forma de evitar la falsificación («fungían de marcas de autenticación» [Petit, 2017, p. 19]), al arte del grabado, que vivió gracias a ello un momento de júbilo no visto antes, desde una perspectiva no solo temporal, sino también espacial, en cuanto España deslumbró con la majestuosidad de sus grabados en tales documentos, a un punto tal que hoy día son muestras preciosas de museo y objetos codiciados por los coleccionistas: «Además de ser títulos-valores las acciones de las reales compañías, los billetes de banco y los vales españoles del siglo XVIII fueron estampas de calidad poco común en otros espacios europeos» (Petit, 2017, p. 18). ${ }^{3}$ Y justo para demostrar su belleza, el libro está acompañado de las imágenes de los mismos.

Lo anterior lleva a nuestro autor a analizar con cuidado los grabados y sus recursos estéticos, los cuales solo cobran sentido para el espectador contemporáneo 230 desde una historia de la cultura, pues, por dar un ejemplo, el continuo recurso a la iconografía religiosa buscaba legitimar, ante el pueblo creyente español, el crédito público que reposaba en unos papeles que, de otra manera, no tendrían mayor valor representativo (Petit, 2017, p. 16). Así, podría decirse, el arte no

\footnotetext{
2 De acuerdo con Petit (2017, p. 15): «El siglo ilustrado asistió al declive de una concepción transcendente del mundo y de la existencia humana basada en la virtud de la fe». Incluso, para articular este proceso de desacralización del comercio, es mejor acudir a una obra mayor, de larga duración, sobre la desacralización misma de la sociedad europea. Me refiero a Prodi (2000): Una storia della giustizia: dal pluralismo dei fori al moderno dualismo tra coscienza e diritto.

3 Ver igualmente, el flamante capítulo III: «El poder y la talla dulce: consideración de los vales reales» (Petit, 2017, pp. 31-77).
} 
se agota en sus posibilidades de ser, en sí mismo, sino que exige, por más dolor que esto le genere a los puristas, una remisión a la cultura que le rodea.

Entonces, el crédito público español en el siglo ilustrado se fundó -como creencia que llenaba los espacios que paulatinamente dejó expuesta la fe católica (corporativa y escolástica) en lo que atañe al gobierno (Decock, 2013)-, de un lado, en la confianza misma que daba una persona reputada como honorable (y por ello «condecorada» ${ }^{4}$ según la usanza de la época), y, del otro, en la seguridad y la belleza que aportaba el arte del grabado.

De esta manera, el comercio, el derecho mercantil y el arte del grabado vivieron un momento de gran transformación que, en alguna medida, se fue al traste con los duros reveses españoles de principios del siglo XIX. Las guerras españolas de la época (primero contra la Revolución Francesa, luego contra los ingleses -al lado de los franceses-, y de nuevo contra los franceses tras la invasión napoleónica -ahora aliada de Inglaterra-, etc.), sumadas al desmoronamiento del control de las provincias de ultramar gracias a la independencia de muchas de estas últimas, exigieron una cantidad ingente de recursos económicos que la policía intentó conseguir mediante un crédito público generalizado (ya no solo de acceso para mercaderes), pero que no pudo cubrir ni material ni simbólicamente, por lo cual la nueva confianza, la nueva creencia en los documentos que representaban una deuda pública, se desvaneció. La pérdida de credibilidad en los nuevos mercados ampliados significó el fracaso de la estrategia pragmática de los gobiernos borbónicos ilustrados de acceder a fuentes novedosas de ingresos. Y esta decadencia de la credibilidad de las «personas condecoradas» que soportaban, con su firma, los documentos del crédito público supuso también una decadencia del arte del grabado español, el cual nunca volvió a ser el mismo (Petit, 2017, pp. 147-148). Por todos estos impases, el rápido crecimiento del crédito público se detuvo y hubo de esperar todo un siglo para poder presenciar, de mejor manera, su instauración definitiva.

Así, con base en este sucinto pero -espero- emotivo recuento, no queda más que invitar al lector a abrir dicho libro, el cual, junto a la Historia del derecho mercantil al que se agrega, permite una mejor comprensión de la transición entre Antiguo Régimen y modernidad liberal, no solo en lo que compete al derecho

\footnotetext{
4 En alusión a: «aponer sobre los eventuales billetes de banco la firma del síndico personero madrileño o de algún notable de los Cinco Gremios y aun "de cualquier persona pública y condecorada" se entendería necesario para "cimentar la confianza [del público], sin la cual el proyecto era vano"» (Petit, 2017, p. 20, citando un documento de 1794).
} 
comercial, sino también en otros dos campos que, gracias a la obra reseñada, se le relacionan claramente: el arte y la economía.

\section{Bibliografía}

Conde, E. (2006). «Libros de policía, policía de libros: España, 1800». Quaderni Fiorentini per la storia del pensiero giuridico moderno (35), T. 1, 557-592.

Decock, W. (2013). Theologians and Contract Law: The Moral Transformation of the Ius Commune (ca. 1500-1650). Leiden - Boston: Martinus Nijhoff Publishers.

Grossi, Paolo (2003). Mitologie giuridiche della modernità. Milano: Giuffrè editore.

Mannori, L. y Sordi, B. (2013). Storia del diritto amministrativo. Roma - Bari: Laterza.

Martínez Gijón, J. (1999). Historia del derecho mercantil. Estudios. Sevilla: Publicaciones de la Universidad

Petit, C. (s.f.). El envite ilustrado: Real lotería y proyectos de poder en el siglo XVIII. Texto inédito.

Petit, C. (2016). Historia del derecho mercantil. Madrid: Marcial Pons.

Petit, C. (2017). Arte y derecho mercantil: Imagen y concepto de los títulos-valores en la España ilustrada. Madrid: Marcial Pons.

Prodi, P. (2000). Una storia della giustizia: dal pluralismo dei fori al moderno dualismo tra coscienza e diritto. Bologna: Il Mulino. 